Національний університет “Львівська політехніка”, кафедра спеціалізованих комп’ютерних систем

\title{
МЕТОД ВИЗНАЧЕННЯ ВІДДАЛІ ДО ДЖЕРЕЛА АКУСТИЧНИХ СИГНАЛІВ
}

(C) Трембач Б. Р., 2016

Проаналізовано існуючі методи та засоби застосування акустичних сигналів у різних галузях промисловості. Показано перспективу розвитку теорії та методів удосконалення інформаційних систем та пристроїв визначення віддалі до джерела акустичних сигналів на основі їх градіснтного та кореляційного опрацювання. Запропоновано метод градіснтного опрацювання акустичних сигналів та інформаційну технологію розв'язання задачі визначення віддалі до джерела акустичних сигналів. Систематизовано просторові геометрії різного розміщення джерел та приймачів акустичних сигналів. Оцінено діаграми розсіювання акустичних сигналів та загасання їх потужності $\mathbf{y}$ середовищі поширення. Розроблено принципи покращення характеристик, оцінено переваги та функціональні обмеження запропонованого методу.

Ключові слова: акустичний сигнал, градіснтний метод.

\section{METHOD OF DETERMINING THE DISTANCE TO THE SOURCE OF ACOUSTIC SIGNALS}

(C) Trembach B. R., 2016

The analysis of existing methods and means of application of acoustic signals in different branches of industry. Prospects for further development of theory and methods for improving information systems and devices determination of the distance to the source of acoustic signals based on their gradient and correlation processing have been shown. The proposed method of gradient-processing acoustic signal and information technology solving the problem of determining the distance to the source of acoustic signals. Spatial geometry for different location of sources and receivers of acoustic signals was systemized. Acoustic signals dissemination charts and fading of their intensity in the propagation medium were estimated. Principles to improve performance were developed, evaluated the advantages and functional limitations of the proposed method.

Key words: acoustic signal, gradient method.

\section{Ветуп}

Методи опрацювання та розпізнавання акустичних сигналів поширені у теорії та практиці вимірювання різних технологічних параметрів безконтактним способом [1], а також визначення віддалі до джерела акустичного сигналу (ДАС) [2,3].

Математичною основою таких методів $є$ формалізація та моделювання фізичних процесів створення та поширення акустичних сигналів (АC) у різних середовищах. Прикладом таких успішних застосувань є градієнтне опрацювання АС при вимірюванні питомої ваги рідин градієнтним методом у хімічній та нафтогазовій галузях промисловості на основі звукових АС у

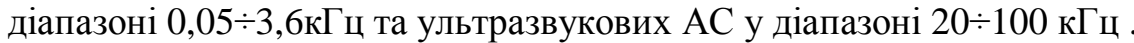

Іншим успішним застосуванням вимірювань та опрацювання $\mathrm{AC} \epsilon$ кореляційні методи, які дають змогу суттєво покращити відношення сигнал / шум в умовах завад. Такі промислові корелятори призначені для виявлення місць витоків рідин та газів у трубопроводах водо- та газопостачання міст, а також у магістральних нафто- та газопроводах [4]. 
За відсутності можливості кореляційного опрацювання АC, наприклад, коли швидкодія корелятора недостатня для обчислення функцій авто- та взаємокореляцій у реальному часі або за значної складності та великої вартості таких пристроїв, що випускаються відомими фірмами [5-7], необхідне обгрунтування та вдосконалення методу градієнтного опрацювання АС. Така наукова задача $\epsilon$ актуальною для багатьох практичних застосувань у різних галузях промисловості та у спецтехніці.

\section{Аналіз останніх досліджень та публікацій}

Існує низка класифікованих двовимірних просторових моделей розміщення ДАС і ПАС, зокрема: градієнтна; симетрична; асиметрична; радіальна; зіркова, яким відповідають моделі 3 особливими характеристиками геометрії.

Очевидно, що залежно від класу спостережуваної геометрії просторового розміщення ДАС і ПАС відповідно змінюватимуться математика та складність алгоритмів градієнтного та кореляційного опрацювання АС з метою ідентифікації просторового положення ДАС визначенням базових значеннь кута $\alpha$ та віддалі $L_{x}$ між ДАС та одним із просторово ідентифікованих ПАС.

Прикладом успішного розв'язання задачі ідентифікації просторового розміщення ДАС і ПАС для визначення координати цілі є принцип роботи системи звукової артилерійської розвідки [2] на основі асиметричної геометрії.

У роботі [2] викладено методологію визначення координат ДАС на основі заданого розміщення ПАС, тобто звукоприймачів, розміщених на певній відстані між собою. Пара звукоприймачів утворює акустичну базу, що дозволяє визначати напрям на ціль. Принцип роботи акустичної бази схематично зображено на рис. 1. В точках А та В знаходяться звукоприймачі, відстань відрізка $\mathrm{AB}$ називають довжиною акустичної бази. Нехай в точці О знаходиться ціль, що виявила себе звуком пострілу, тоді від неї у всіх Рис. 1. Схема розташування елементів акустичної бази напрямках зі швидкістю звуку розповсюджуються акустичні хвилі, які, пройшовши шлях S1, реєструються звукоприймачем в точці A, а пройшовши шлях $\mathrm{S} 2$, у B.

Тоді справджується співвідношення

$$
\left\{\begin{array}{l}
S 1=c \times t_{1} ; \\
S 2=c \times t_{2},
\end{array}\right.
$$

де $c$ - швидкість розповсюдження звуку у атмосфері; $t_{1}$ та $t_{2}$ - часи проходження акустичних хвиль відстані $S 1$ та $S 2$ відповідно.

Нехай точка С лежить на відрізку ВО так, що довжина відрізка СО дорівнює довжині відрізка $\mathrm{AO}$, тобто звук пострілу одночасно реєструється в точках $\mathrm{A}$ та $\mathrm{C}$, а точки $\mathrm{D}$ та $\mathrm{N}$ розташовано так, що довжини відрізків BD та DA однакові (точка D лежить посередині відрізка AB), а кут NDA $\epsilon$ прямим (відрізок DN $\epsilon$ нормаллю до відрізка $\mathrm{AB}$, який в артилерії прийнято називати директрисою акустичної бази). Якщо довжина відрізка $\mathrm{AB}$ значно менша від довжин відрізків $\mathrm{AO}$ та $\mathrm{BO}$, то значення кута АCB прямує до $90^{\circ}$ [3]. У такому випадку відрізки ВС та СА - катети прямокутного трикутника $\mathrm{ABC}$, а відрізок $\mathrm{BA}$ - його гіпотенуза. Кут NDO дорівнює куту САВ і для нього справджується

$$
\sin (C A B)=\sin (N D O)=\frac{B C}{B A}=\frac{\left(t_{2}-t_{1}\right) \times C}{B A}=\frac{\Delta t \times C}{L_{0}},
$$

де $\Delta t$ - різниця часу реєстрації звуку пострілу між двома звукоприймачами; $L_{0}$ - довжина акустичної бази. 
Отже, вихідними даними при розрахунку напрямку на ціль $є$ різниця часу реєстрації звуку між двома звукоприймачами, відстань між ними та орієнтація акустичної бази на місцевості. Для визначення координати цілі необхідно визначити напрямки на ціль із як мінімум двох акустичних баз. Причому один і той самий звукоприймач може входити до складу декількох акустичних баз.

Спрощення алгоритму обчислення значення кута напрямленості ДАС САВ ( $\beta$ ) згідно 3 виразом (2) можна досягти вибором базової віддалі між ПАС1 та ПАС2 $L_{0}$, що дорівнює $2^{\mathrm{n}}$. Наприклад: $L_{0}=16,32,64,256$ м, що дає змогу спростити виконання операції ділення на $L_{0}$ у виразі (2) відніманням відповідного числа двійкових розрядів у добутку $\Delta t \times c$, тобто 4, 5, 6, 8 біт.

Інакше можна спростити алгоритм обчислення (2) заданням $L$, кратним швидкості поширення звуку в атмосфері $c=330 \mathrm{M} / \mathrm{c}$. Тобто вибрати $L=k^{*} c$ серед значень 0,$33 ; 3,3 ; 33 ; 330 \mathrm{M}$, що дозволить виключити операцію ділення у виразі (2) i виконувати обчислення згідно 3 виразом $\sin (\mathrm{CAB})=\sin (\beta)=(\Delta t \times c) / L_{0}=k \times \Delta t$, що суттєво спрощує цифрову реалізацію спецпроцесора визначення напряму на ДАС.

Необхідність ефективного розпізнавання та ідентифікації сигналів одного 3 пеленгованих ДАС відносно просторової геометрії ПАС на фоні шумів потребує кореляційного опрацювання АС. Прикладом застосування багатоканальної кореляційної системи для просторової ідентифікації ДАС $€$ акустична локалізація накопиченої кореляції $[8,9]$, структуру якої показано на рис.2.

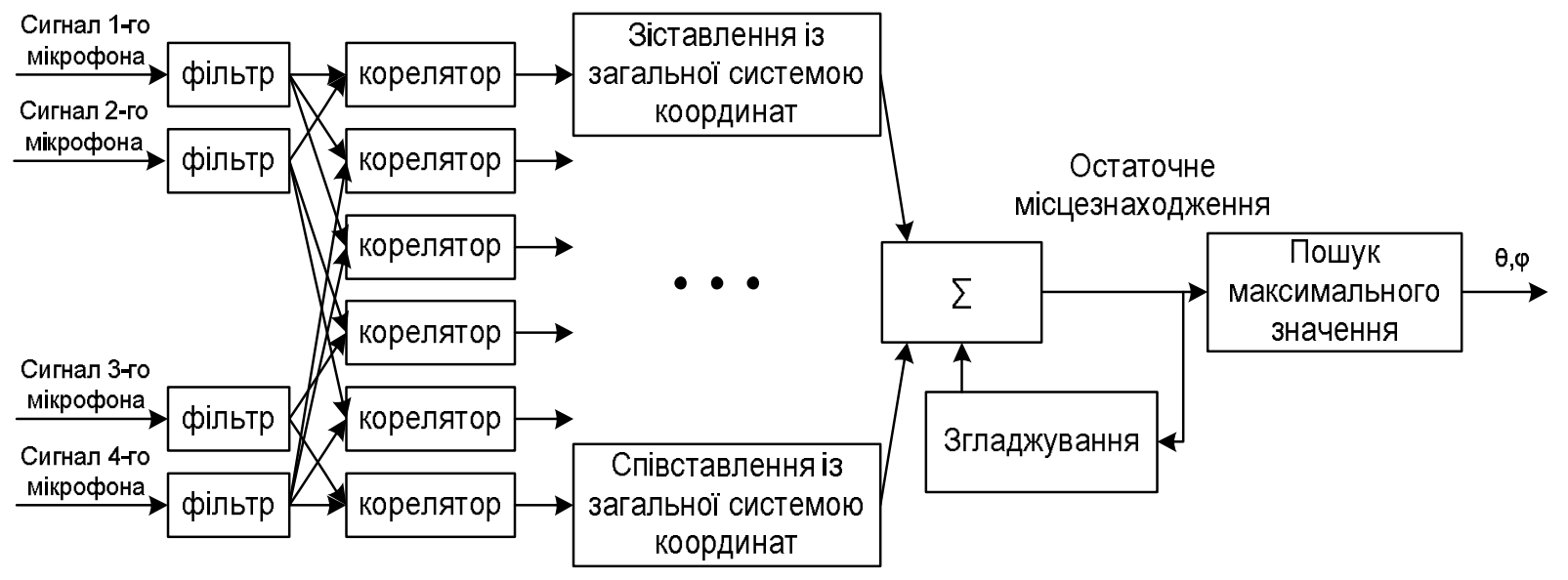

Рис. 2. Структура кореляційної системи просторової ідентифікації ДАС

3 рис. 2 видно, що із застосуванням 4-х акустичних сенсорів достатньо визначення 6-ти взаємокореляційних функцій $\operatorname{Rxy}(\tau)$, що випливає 3 симетрії взаємокореляційної матриці mканального корелятора:

$$
\begin{array}{cccc}
1 & R_{12} & R_{13} & R_{14} \\
- & 1 & R_{23} & R_{24} \\
- & - & 1 & R_{34} \\
- & - & - & 1
\end{array}
$$

Очевидно, що при мінімально необхідному числі акустичних сенсорів (m=3) число кореляторів буде дорівнюватиме трьом (R12, R13, R23).

Як аналітичний вираз для розрахунку функції взаємокореляції системи ідентифікації сигналів одного ДАС у роботі [8] запропоновано інтегральну функцію опрацювання аналогових АC:

$$
L(q)=G\left(\int_{\tau(i, q)-\frac{w}{2}}^{\tau(i, q)+\frac{w}{2}} x_{i}(t) \times x_{j}\left(t-\tau_{i, q}+\tau_{j, q}\right) d t\right)+\alpha V_{E},
$$

де $x_{i}(t)$ та $x_{j}\left(t-\tau_{i, q}+\tau_{j, q}\right) \quad-$ відповідно прийняті ПАС1 та із запізненням ПАС2 АС; $\alpha V_{E}-$ коефіцієнт загасання енергії. 
Як показано в роботах $[10,11]$, визначати функції взаємокореляції можна на основі 8-ми аналітичних виразів, які наведено у табл.1.

Аналітичні вирази оцінок дискретних взаємокореляційних функцій $W_{x y}(\tau)$

\begin{tabular}{|c|c|c|}
\hline № & Кореляційна функція & Автокореляційна функція \\
\hline 1. & Знакова & $H_{x x}(j)=\frac{1}{n} \sum_{i=1}^{n} \operatorname{sign}\left(x_{i}\right) \cdot \operatorname{sign}\left(x_{i+j}\right)$. \\
\hline 2. & Релейна & $B_{x x}(j)=\frac{1}{n} \sum_{i=1}^{n} x_{i} \cdot \operatorname{sign}\left(x_{i+j}\right)$. \\
\hline 3. & Коваріаційна & $K_{x x}(j)=\frac{1}{n} \sum_{i=1}^{n} x_{i} \cdot x_{i+j} \cdot$ \\
\hline 4. & Кореляційна & $R_{x x}(j)=\frac{1}{n} \sum_{i=1}^{n} x_{i} \cdot x_{i+j} \cdot$ \\
\hline 5. & Структурна & $C_{x x}(j)=\frac{1}{n} \sum_{i=1}^{n}\left(x_{i}-x_{i+j}\right)^{2}$. \\
\hline 6. & Модульна & $G_{x x}(j)=\frac{1}{n} \sum_{i=1}^{n}\left|x_{i}-x_{i+j}\right|$. \\
\hline 7. & Еквівалентності & $F_{x x}(j)=\frac{1}{n} \sum_{i=1}^{n} z_{x x}$. \\
\hline
\end{tabular}

Обгрунтування та вибір конкретної функції взаємокореляції, аналітичні вирази яких наведено в табл. 1, за умов їх ефективного застосування при розв'язання задачі програмної чи апаратної реалізації засобів опрацювання АС є окремим науковим.дослідженням 3 врахуванням вимог необхідної швидкодії обчислень, а також оцінок критеріїв алгоритмічної, структурної, функціональної та апаратної складності.

При цьому необхідно також враховувати різні потенціальні можливості швидкодії кореляційних обчислень із застосуванням різних систем числення та кодових систем широкого класу теоретико-числових базисів (ТЧБ): унітарного, Хаара, Радемахера, Крестенсона, Радемахера Крестенсона, Хаара - Крестенсона та Галуа [12].

Досвід розроблення спеціалізованих процесорів кореляційного опрацювання сигналів із застосуванням кодових систем різних ТЧБ дає змогу зробити обгрунтований вибір відповідної аналітики та структури спецпроцесора для успішного розв'язання задачі.

Традиційна найпоширеніша реалізація цифрових кореляторів за мультиплікативною функцією $R x y(j)$ на основі перемноження центрованих та нормованих оцифрованих значень АС згідно 3 математикою двійкових чисел ТЧБ Радемахера $\epsilon$ найбільш громіздкою та низькошвидкісною.

\section{Постановка задачі та формалізація математичної задачі визначення градіснтним методом віддалі до ДАС}

У загальному випадку математична основа задачі визначення віддалі до ДАС належить до класу задач розпізнавання образів згідно 3 теорією оцінювання хеммінгової віддалі між формалізованими та кластеризованими образами чи сигналами складної структури на основі обчислення модульної взаємокореляційної функції $d_{i j}$ згідно з виразом [13]:

$$
d_{i j}=\frac{1}{n} \sum_{i=1}^{n}\left|x_{i}-y_{i-j}\right| ; j \in \overline{0, m},
$$

де $x_{i}$ та $y_{i-j}-$ відповідні поточні та затримані у часі $\tau=j$ сигнали, які приймаються двома просторово розміщеними ПАС; $m$ - число точок функції кореляції; $n$ - об’ єм вибірки цифрових значень $x_{i}$ та. $y_{i-j}$ сигналів. 
Залежно від часового зсуву сигналів $x_{i}$ та. $y_{i-j}$ функція (4) має асимптотику, показану на рис. 3.

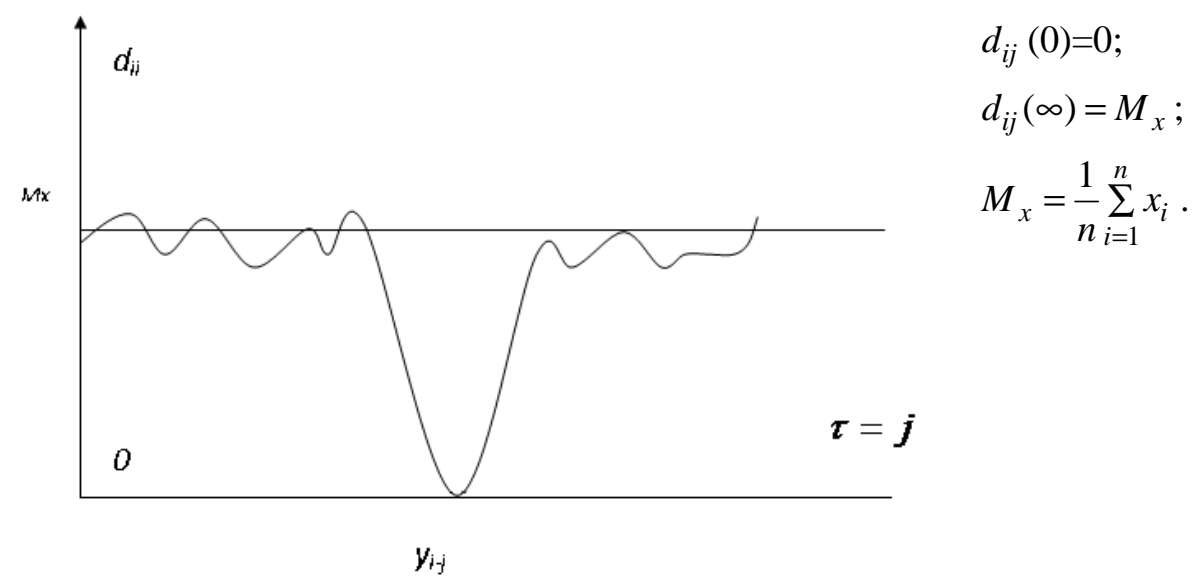

Рис. 3. Асимптотика модульної взаємокореляиійної функиії.

Тобто, у певний момент часу $\tau=j$, де $j$ - дискретна складова часу, можливий збіг обвідних дискретизованих у часі і квантованих за амплітудою цифрових відображень АС:

$$
x(t) \Rightarrow\left\{x_{i}\right\} ; \quad y(t) \Rightarrow\left\{y_{i-j}\right\} .
$$

При цьому у випадку збігу сигналу у певний момент часу значення інтегральної оцінки хеммінгової віддалі наближається до нуля, як це показано на рис. 3.

\section{Теоретичні засади градіснтного методу опрацювання АС}

Розглянемо задачу визначення віддалі до ДАС на основі двох ПАС, розміщених на певній віддалі між собою за фронтом поширення АС. У цьому частковому випадку розміщення ДАС відоме, оскільки $\alpha=0^{\circ}$.

Суть градієнтного методу визначення віддалі від ПАС до ДАС полягає у розрахунку різницевої зміни потужності $\Delta P_{c}$ АС при зміні віддалі до ДАС $L_{x}$ (рис. 4).

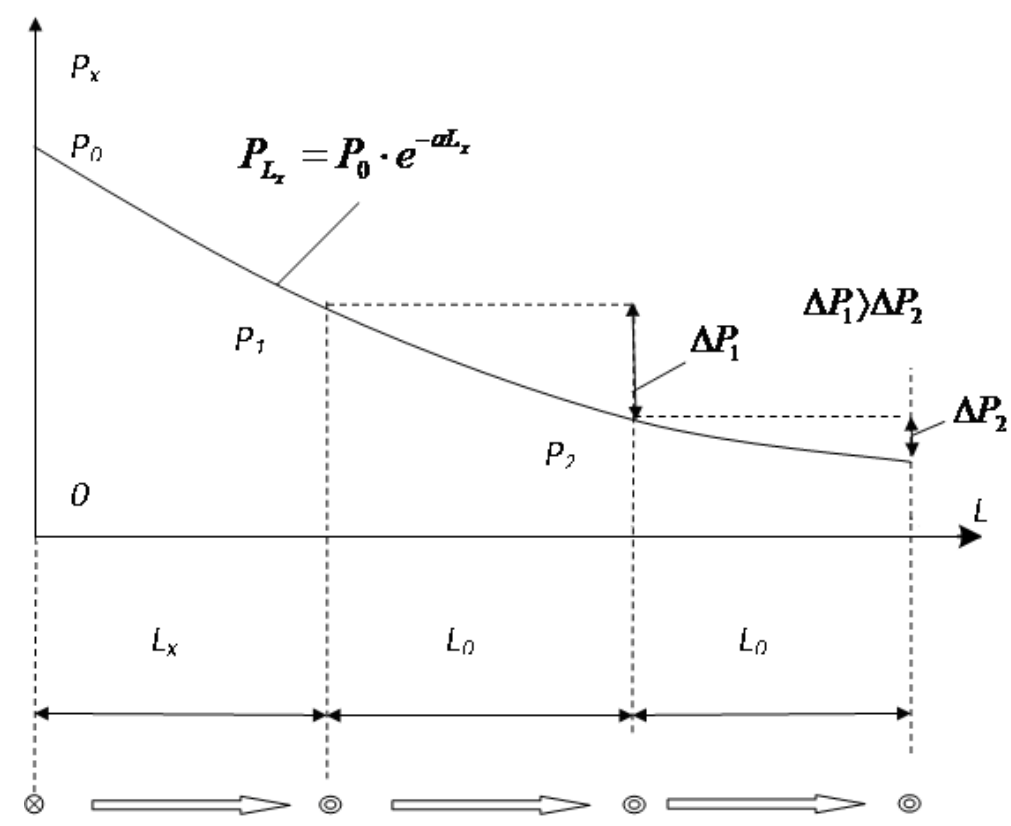

Рис. 4. Характеристика експоненціального загасання потужності АС залежно від віддалей його поширення $L_{x}$ та $L_{o}, \alpha$-коефійінт загасання потужності $A C$ 
Отже, на основі градієнтної моделі поширення АC в атмосфері (рис.4) можна сформулювати алгоритмічну систему таких операцій для визначення невідомої величини віддалі до ДАС $L_{x}$ :

1) безперервний моніторинг АС у напрямі його поширення, який збігається з деяким околом, зумовленим просторовою діаграмою характеристик та чутливості мікрофонів ПАС (рис. 5).

2) визначення різниці між потужностями $\mathrm{AC}$, виміряної на віддалі бази $L_{0}$;

3) розрахунок шуканої віддалі $L_{x}$ до ДАС з врахуванням загасання характеристики АС у середовищі їх поширення.

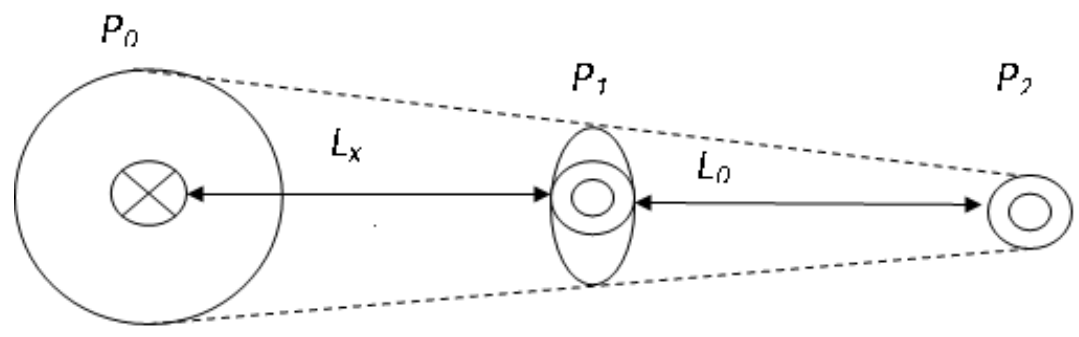

ДАC

Рис. 5. Просторова діаграма зміни потужності $A C P_{o}$ на віддалі $L_{x}\left(P_{1}\right)$ та $L_{x}+L_{o}\left(P_{2}\right)$

3 рис. 4 та рис. 5 видно, що градієнти загасання АС залежно від віддалі від ДАС до ПАС1 $\left(L_{x}\right)$ та до ПАС2 $\left(L_{x}+L_{o}\right) \epsilon$ різні. Тобто

$$
\Delta P_{1}=P_{1}-P_{2} ; \Delta P_{2}=P_{3}-P_{4},
$$

причому величини $\Delta P_{1}$ та $\Delta P_{2} \epsilon$ додатними, оскільки $\left.P_{1}\right\rangle P_{2}$ i $\left.P_{3}\right\rangle P_{4}$, а також $\epsilon$ додатною величиною $\Delta P_{1}-\Delta P_{2}>0$.

Ці властивості зміни потужності АС, які приймаються ПАС, суттєво спрощують математичну та практичну реалізації відповідного алгоритму обчислень на універсальному чи спеціалізованому процесорі на ПЛІС.

Отже, математичною формалізацією досліджуваної задачі визначення віддалі між ДАС і ПАС $\left(L_{x}\right)$ та параметрі загасання $\mathrm{AC}$ у середовищі поширення $\alpha \in$ положення теорії, яка визначає експоненціальну залежність енергії та зменшення потужності залежно від віддалі точкового джерела енергії (оптичної, електромагнітної чи акустичної). Тобто

$$
P_{L_{x}}=P_{0} \cdot e^{-\alpha L_{x}},
$$

де $P_{0}$ і $P_{L_{x}}-$ відповідно миттєві потужності сигналів у точках $L_{x}=0$ та $L_{x}$.

Отже, аналітика визначення віддалі між ДАС і ПАС градієнтним методом за невизначеної величини потужності АС ДАС $P_{0}=v a r$ та відомого значення коефіцієнта загасання кута $\alpha$ та базової віддалі $L_{o}$ між ПАС1 і ПАС2 формулюється за виразом:

$$
\begin{gathered}
\Delta P=P_{1}-P_{2}=e^{-\alpha L_{x}}-e^{-\alpha L_{0}}=e^{-\alpha\left(L_{x}-L_{0}\right)} ; \\
\ln \Delta P=\alpha\left(L_{x}-L_{0}\right) ; L_{x}-L_{0}=\frac{\ln \Delta P}{\alpha} ; L_{x}=L_{0}+\frac{\ln \Delta P}{\alpha} .
\end{gathered}
$$

При реалізації спеціалізованого засобу визначення віддалі до ДАС градієнтним методом використання функції натурального логарифма неефективно, оскільки це ускладнює мікроелектронну реалізацію обчислювача. Ефективніше застосувати функцію двійкового логарифма, який поширений у цифровій комп'ютерній техніці. Тобто ступінь загасання потужності АС залежно 
від віддалі $L_{x}$ можна описати, задавши оцінку $e^{-\alpha L_{x}}$ у вигляді $\frac{1}{k} 2^{-\alpha L_{x}}$, де $k$ 0Ц враховує перехід до двійкового логарифма. Тоді вираз визначення $L_{x}$ набуде вигляду

$$
L_{x}=L_{0}+\frac{\log _{2} \Delta P}{k \cdot \alpha} .
$$

При цьому $\log _{2} \Delta P$ дорівнює двійковому коду $\Delta P$. Якщо добуток $k \cdot \alpha$ дорівнює $2^{n}$, то операція ділення цифрового двійкового коду на цей добуток буде виконуватися відкиданням n.-розрядів від коду $\Delta P$. Тобто спецпроцесор визначення віддалі до ДАС буде реалізований на основі двійкового багаторозрядного швидкодіючого суматора за модулем $n$ коду $L_{2}$ згідно із структурою [14].

Чутливість та точність досліджуваного методу можна підвищити, збільшуючи віддаль рознесення $w L_{o}$ ПАC1 і ПАС2. При цьому відповідно зростає величина $\Delta P$. Іншим принципом підвищення чутливості і відповідно точності визначення віддалі до ДАС $є$ технічне створення спеціалізованого середовища поширення $\mathrm{AC}$ на ділянці $w L_{o}$ з набагато більшим коефіцієнтом його загасання $\left.\alpha_{c}\right\rangle \alpha$, як це показано на рис. 6.

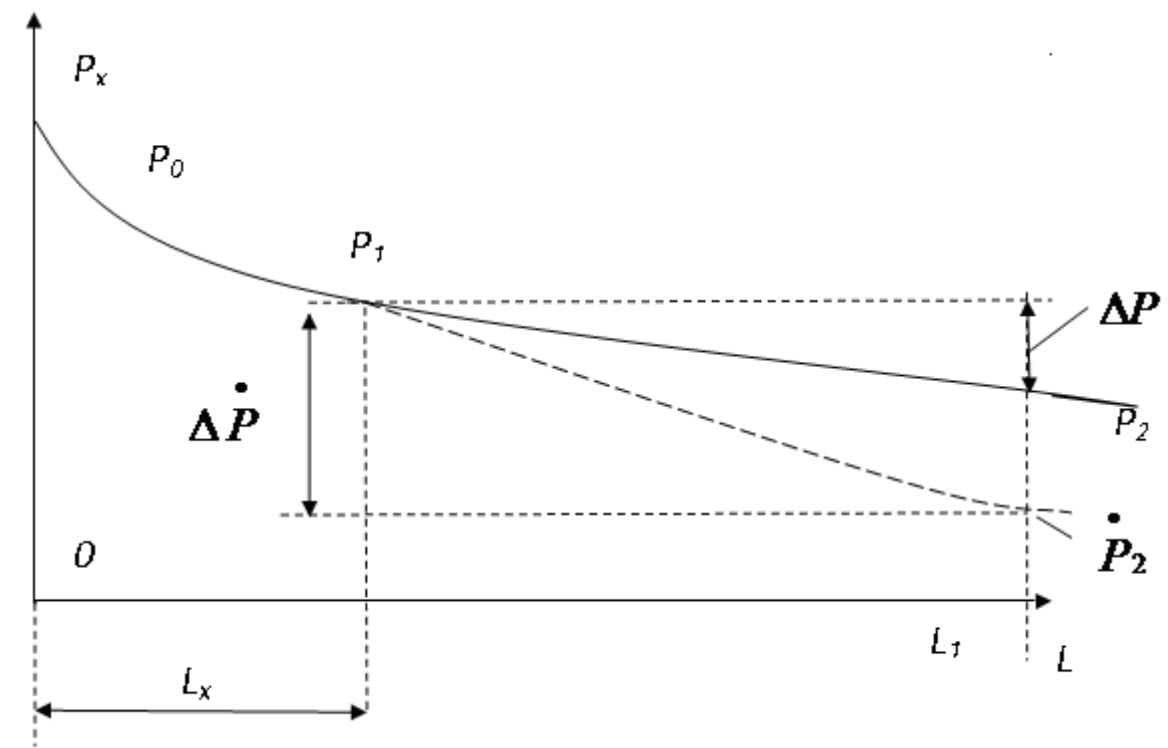

Рис. 6. Принщипи підвищення чутливості градієнтного методу визначення віддалі до ДАС

У випадку, якщо застосовують технічний принцип підвищення чутливості градієнтного методу збільшенням коефіцієнта загасання потужності $\mathrm{AC}$ на віддалі $L_{o}$, обчислюють $L_{x}$ за виразом

$$
L_{x}=L_{0}+\frac{\log _{2} \Delta P}{k \cdot \alpha \cdot k_{0}},
$$

де $k_{o}$ - коефіцієнт, що враховує технічне загасання $\mathrm{AC}$ на ділянці $L_{o}$.

Слід зауважити, що ефективність застосування запропонованого градієнтного методу визначення віддалі до ДАС залежить від таких переваг та функціональних обмежень:

1. Перевагою градієнтного методу є незалежність правильного визначення шуканої віддалі до ДАС $L_{x}$ від початкової потужності $P_{0}$ ДАС, що не потребує додаткових знань про пікову потужність ДАС (рис. 7). 


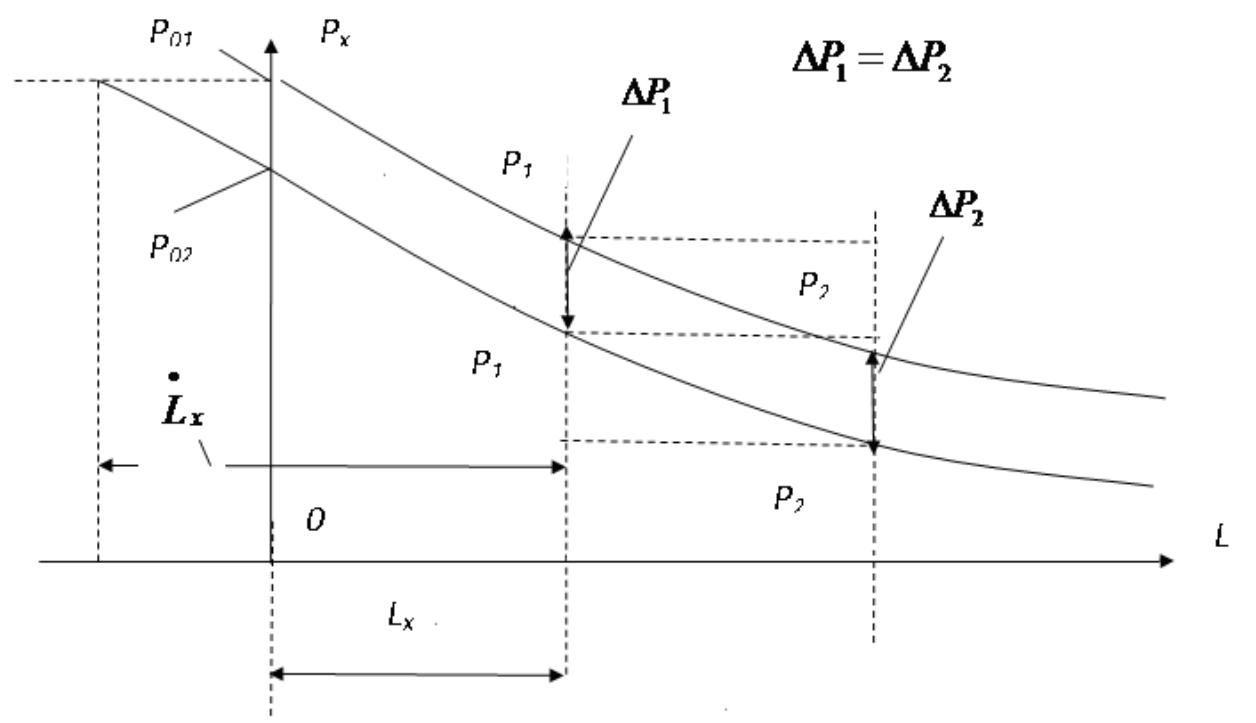

Рис. 7. Характеристики загасання потужності АС за різних $P_{01}$ ma $P_{02}$

2. Перевагою градієнтного методу $є$ можливість врахування впливу мультиплікативної завади (як це показано на рис. 8) як методичної похибки, загасання потужності АС, зумовленої рельєфом, характером місцевості (водна поверхня, ліс та ін.), а також атмосферними факторами (дощ, туман, вітер), що не потребує корегування результатів обчислень іншими методами моніторингу просторового розміщення ДАС, а також визначення пікової потужності $P_{0}$ ДАС розпізнаванням та ідентифікацією типу ДАС із заданою відомою піковою потужністю (наприклад, гармата, міномет чи стрілецька зброя).

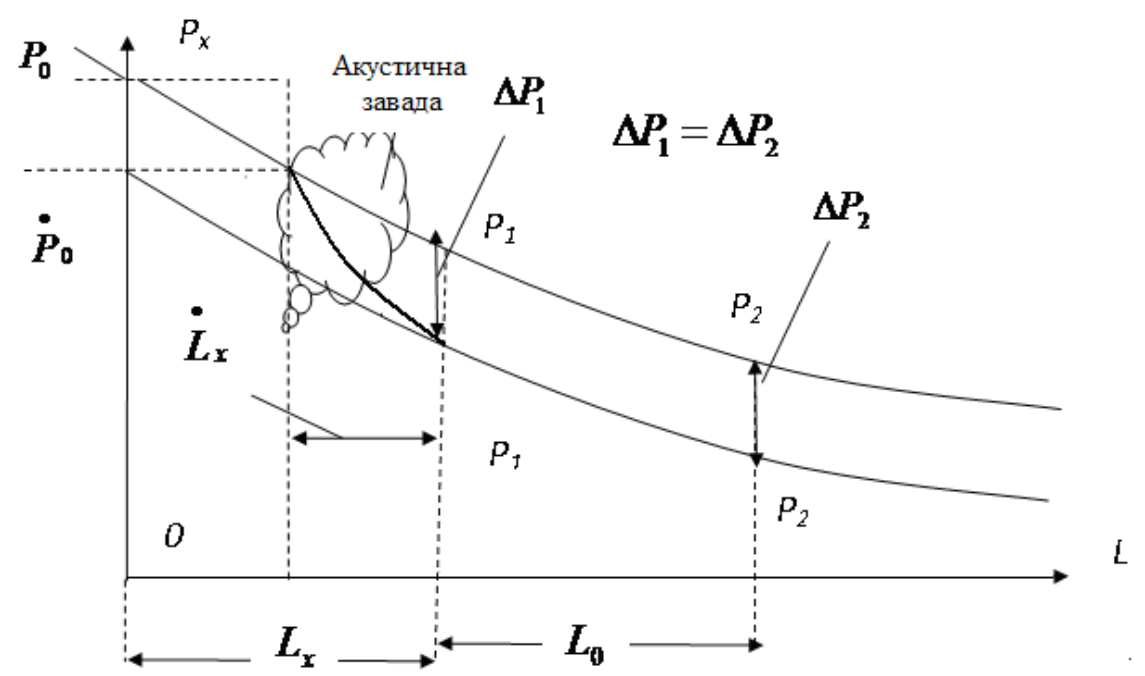

Рис. 8. Вплив мультиплікативних завад на точність градієнтного методу

3. Перевагою методу є відсутність необхідності просторової пеленгації ДАС не менше як трьома ПАС.

\section{Висновки}

Запропоновано метод градієнтного опрацювання акустичних сигналів та технологію визначення відстані до джерела акустичних сигналів цим методом. Систематизовано різноманітні варіанти розміщення джерел та приймачів акустичних сигналів. Оцінено рівні розсіювання та загасання акустичних сигналів у середовищі поширення. Викладені теоретичні засади 
запропонованого методу градієнтного визначення віддалі до джерела акустичного сигналу, способів спрощення обчислень та принципів підвищення його чутливості і точності окреслюють визначену перспективу створення відповідних технічних та програмно-апаратних засобів, які можна ефективно застосувати у практиці акустичних вимірювань та техніці спеціального призначення.

1. Патент Украӥни на корисну модель № 37774 , МПК: G01N 29/00. Кореляційний спосіб вимірювання швидкості звуку в матеріалах / О. Л. Сторожук, В. М. Борисов, Я. І. Соколовський. Опубліковано: 10.12.2008. Бюл. №2 3. 2. Кочан Р. В. Концепція розподіленої автоматичної системи звукової артилерійської розвідки на базі стільникового зв'язку / Р. В. Кочан, Б. Р. Трембач // Сучасні інформачійні технології у сфері безпеки та оборони. - 2016. - №1 (25). - С. 59-63. 3. Кривошеєв А. М. Основи артилерійської розвідки: навч. посібник / А. М. Кривошеєв, В. М. Петренко, А. І. Приходько. - Суми: Сумський державний університет, 2014. - 393 с. 4. Ширмовська Н. Г. Застосування кореляиійного та кластерного аналізу для ідентифікації передаварійних та аварійних станів прочесів буріння / Н. Г. Ширмовська, І. Б. Албанський, I. Р. Пітух, О. Л. Кулинин // Науковий вісник ІФНТУНГ. - 2011. - № 3(29) - C. $179-186$. 5. [Електронний ресурс]. - Режим доступу: www.analog.com-офіuійний caŭm фірми Analog Devices. 6. [Електронний ресурс]. - Режим доступу:www.maxim-ic.com-офіційний сайт компанї̈ Maхіт. 7. [Електронний ресурс]. - Режим доступу:www.motorola.com-офіційний сайт компанї Motorola. 8. Birchfield S. T., Gillmor D. K.. Acoustic Localization by Accumulated Correlation. Original: http://www.ces.clemson.edu/ stb/research/acousticloc/. 9. Birchfield S. T. A Unifying Framework for Acoustic Localization, / S. T. Birchfield // Proceedings of the 12th European Signal Processing Conference (EUSIPCO) .- Vienna, Austria.-2004. 10. Николайчук Я. М. Теорія джерел інформації / Я. М. Николайчук.//Монографія. - Тернопіль: ТНЕУ, 2008. - 536 с 11. Albanskiy Ivan. Theory and Special Processors of Spectral Cosine Fourier Transformation Based on Various Correlation Functions in Hamming Space./ Albanskiy Ivan, Volodymyr Pikh, Tetyana Zavedyuk, Galina Korniychuk // Proceedings of the XI-th International Conference "Modern Problems of Radio Engineering, Telecommunications and Computer Science” (TCSET-2014).-L'viv-Slavske.-2014. - Р. 677-679. 12. Николайчук Я. М. Коди поля Галуа: теорія та застосування: монографія / Я. М. Николайчук. - Т.:Тернограф, 2012. - 575 с. 13. Хэмминг Р. В. Теория кодирования и теория информации. Пер. с англ. - М.: Радио и связь, 1983. - 176 с. 14. Патент на корисну модель України. №97162, G06F 7/00. Пристрій додавання багаторозрядних двійкових чисел / Я. М. Николайчук, В. Л. Кімак, Б. Б. Круліковський. Опубліковано: 10.03.2015, бюл. № 5 . 